\title{
TAVASTSTJERNA
}

\section{PÅ DET DANSKE BOGMARKED}

FRA PETER NANSENS ARKIV

AF

TORBEN NIELSEN

$\mathrm{D}$

et moderne gennembrud var som bekendt i høj grad et fællesnordisk anliggende. Georg Brandes anerkendtes vel almindeligt som føreren, men man må ikke deraf lade sig forlede til at tro, at radikalismen i Norge og Sverige var en slags filialer af den danske; det var de fælles forudsætninger, der gav næring til en samstemt reaktion. Ligesom Finland $\mathrm{i}$ det store og hele havde stået uden for århundredets tidligere fællesnordiske bevægelser, ligger landet halvfjerdserne igennem ret isoleret fra det øvrige Nordens åndelige liv. Først i 1860 blev det tilladt at anvende det finske sprog $\mathrm{i}$ andre skrifter end opbyggelige og okonomiske, og det betød naturligvis, at en stor del af landets skabende kræfter samledes om at kultivere dette sprog, således at det til den berammede tid, I883, med føje kunde indtage pladsen som officielt sprog ved siden af det svenske; d.v.s. allerede nu fandtes de, der sigtede videre, og i ligestillingen kun så en station på vejen til herredommet, hvad der naturligvis fremkaldte reaktion på svensk side. En sådan problemstilling kan frembringe frugtbar begejstring lige så vel som smålighed og snæversyn, og da Finland blev delagtigt i det moderne gennembrud, var reaktionen mod den nærsynede partideling en vasentlig forudsatning.

Da Werner Söderhjelm i I883 var på et studieophold i München, fik han $\mathrm{i}$ et brev fra litteraturhistorikeren Valfrid Vasenius den korte karakteristik af forholdene hjemme, at man der kun horte, at Tavaststjerna var stor og Neiglick hans profet. Ordvalget tyder på et vist forbehold; Vasenius var efter samtidig dansk sprogbrug nærmest moderat, og de omtalte personer var ganske unge mennesker, kun 23 år gamle, men den citerede dom har vist sig også at vare eftertidens; det 
var de to, digteren og kritikeren, der gav de moderne idéer i Finland deres gennemslagskraft.

Den mest bevidste forkamper for realismen i kunst og videnskab var Hjalmar Neiglick. I de yngste år stilede han mod en litterær fornyelse $o g$ fandt i Karl August Tavaststjerna et vehikel for sine bestrabelser, men kastede sig senere over experimentalpsykologien; hans studiefalle Alfred Lehmann har en menneskealder senere karakteriseret ham som det intelligenteste menneske, han nogensinde havde truffet. Med sin begavelse $\mathrm{og}$ ildhu forenede han et verdensmandsvasen med udtalt parisisk prag, han var netop typen på, hvad man dengang forstod ved „europaer". At han let vandt indpas i det radikale Kobenhavn, siger sig selv, og det undrer ikke, at han til nærmeste omgangsvenner havde Gustav Esmann og Peter Nansen.

Den 26. januar 1886 fik Neiglick plads i „Politiken “ for en artikel "Finlands unge Digter", hvori Tavaststjerna fik en grundig præsentation for det danske publikum. Artiklen er holdt som en anmeldelse af Tavaststjernas anden digtsamling „Nya vers" (1885), og Neiglicks konklusion er, at digtene peger hen på prosaen som det felt, hvor Tavaststjernas fremtidige betydning ligger. Denne dom er farvet af Neiglicks bristende sans for lyrik og af hans onske om, at Tavaststjerna netop skulde udføre den gerning i Finlands svenske litteratur, som for Neiglick var den ene fornødne: den kritiske samtidsskildring. I den finske litteratur var det nye netop begyndt at spire med Juhani Aho og Minna Canth. Eftertiden har ikke givet Neiglick ret; det er ikke meget af Tavaststjernas prosa, der står sig mod hans bedste vers; af romanerne kun „Hårda tider“. Inden året var omme, udsendte Tavaststjerna imidlertid sin forste roman „Barndomsvänner"; kort efter kom han til $\mathrm{K} \emptyset$ benhavn på sit første længere ophold.

Neiglicks bedømmelse var ikke ubetinget gunstig og kunde efter den målestok, han anvendte, heller ikke blive det; hvorledes han vilde have bedømt Tavaststjernas livsgerning under eet, må forblive gætning; Neiglick døde allerede i 1889 som fungerende filosofiprofessor i Helsingfors.

Tavaststjerna havde dog givet sin litteratur dens forste realistiske samtidsroman, og dette i forbindelse med Neiglicks anbefaling har ikke gjort det urimeligt, om man i det litteræere venstre så hen til den 26-årige forfatter som et onskeligt krafttilskud. Som kampformation stod det litterære venstre dog ikke til at redde, og det er vist også tvivlsomt, hvor megen glæde man vilde have haft af Tavaststjerna som partifælle; han var og blev en løsgænger. Men som sådan ydede de toneangivende københavnske kredse ham en anerkendelse, som han ikke har vundet 
sig bedre andensteds, anført af Georg Brandes, hvis rosende ord om „Hårda tider" og varme mindeord oftere er citeret. Den, der gjorde den største praktiske indsats for at skaffe Tavaststjerna læsere i Danmark, var imidlertid Peter Nansen.

I Peter Nansens arkiv på Det kongelige Bibliotek ligger ialt 39 breve fra Tavaststjerna, som desværre må være ene om at afspejle de to for-

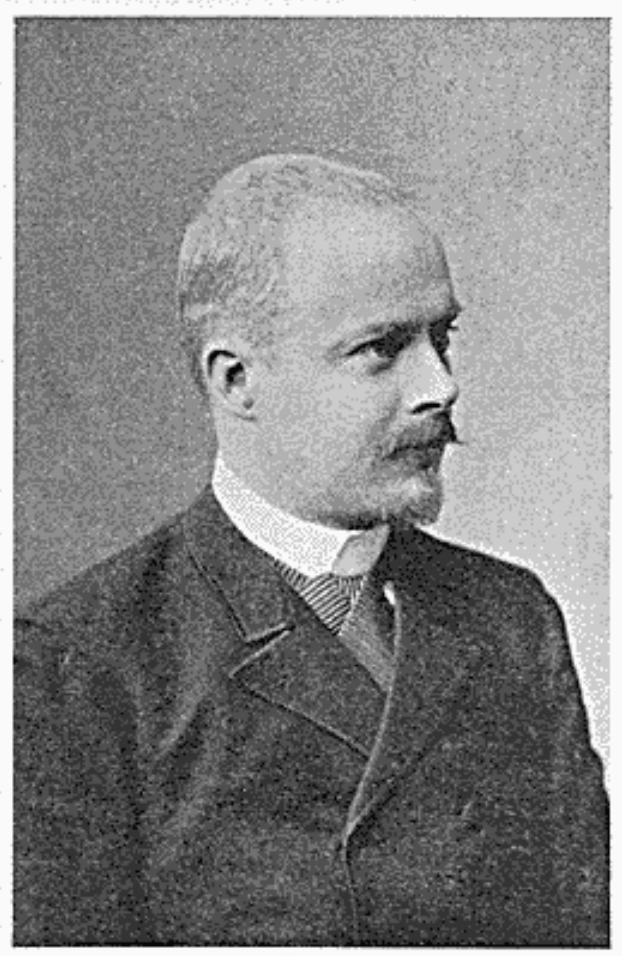

Karl August Tavaststjerna. Fot, Stockholm ca, rees.

Tilhorer Abo Akademis bildsamlingar.

fatteres forhold, da Nansens ikke er bevaret. Vi får altså ikke Nansen selv at se, tilskyndende og frarådende og diplomatisk snoende sig udenom, men gennem Tavaststjernas breve ser vi alle faserne spejle sig. Og vi ser et af de mange exempler på den tillid, Nansen omfattedes med.

Kobenhavneropholdet 1887 har ikke afsat spor i denne brevvexling; forste gang, Tavaststjerna optræder i Nansens brevsamling, er under hans andet store ophold i Kobenhavn, den 8. april 189r. Brevet er i sig sclv uden interesse, en middagsinvitation til Tavaststjernas hotel (Leopold i Hovedvagtsgade, hvor T. iøvrigt tilfældigvis kom til at bo i det 
varelse, hvor Victoria Benedictsson tog sit liv), hvor også Esmann vilde indfinde sig. Tavaststjerna har således overtaget Neiglicks venner.

Det er forst, efter at „Hårda tider" er udkommet, at Nansen for alvor synes at blive interesseret. I efteråret $1^{8} 89^{2}$ passerer Tavaststjerna København og forsøger formentlig at vakke interesse for bogen; den II. december sporger han fra Montreux, om Nansen har læst den, om han tror, at Hegel vil tage den, og endelig beder han om Hegels nøjagtige titel, da han også vil skrive til ham i samme anledning. Nansens svar må have været ret omgående og positivt, for allerede den 28 . december ser sagen ud til at være i fuld gang:

Käre Nansen!

Montreux, poste restante 28. Dec. 92 .

Ert sista vänliga meddelande bar några spår af vädjan till min snålhet eller klokhet. Annars vore det öfverflödigt att jag med handen på hjärtat försäkrade Er det jag ingen sämre eller bättre öfversättare vill ha än Er. Jag kan döma af flera omständigheter att mina arbeten ej gärna kunna råka $\mathrm{i}$ bättre öfversättarhänder än edra. Och då släpper man ej köttstycket för spegelbilden i vattnet, äfven om det vore inlindadt i två hundrakronors sedlar mer, än det värkliga.

$\mathrm{Om}$ nu Hegel ändtligen ville ge Er afgörande besked, så att denna öfversättningsfråga vore undanstökad!

Han har redan talat med mig om mina följande, nya arbeten, dem han ville ha öfversatta ur manuskriptet. Jag hoppas det bästa af honom, och tillfogar bara att min högsta önskan är vidare samarbete oss emellan. - Måtte Ni vara af min åsikt -!

Här arrangerar [man] sig till vinter. Är Politiken för modern för att nöja sig med korrespondanser eller skisser om landskap och meteorologi? Om ej, så sänder jag den snart något småhumoristiskt om nordbornas längtan till södern.

$$
\text { Med vänskap. Er }
$$

Karl A. Tavaststjerna.

Det er ikke at undre sig over, at „Hårda tider" vakte interesse; bedre roman har det svenske åttital ikke frembragt; og Hegel øjner i dens forfatter et nyt led i Gyldendals perlerad af nordiske forfattere. Nansen vil selv oversatte bogen, og i Tavaststjernas almindelige tilfredshed med sagens gang tager han det ikke sâ nøje, at Nansens oversætterhonorar er så betydeligt, at der bliver noget mindre til forfatteren. Han nærmer sig dog dette emne med stor forsigtighed i det omtalte brev til Jacob Hegel, dateret Montreux 18/12 1892 (Kgl. Bibl.); efter Hegels tilsagn om at ville lade hans fremtidige arbejder oversatte efter manuskriptet, 
tænker han sig muligheden af at overgå til Gyldendal som hovedforlag; men desværre må han tage hensyn til sin svage okonomi. Til planen bidrager også hans frygt for censurens skærpelse i Finland. I sit svar har Hegel åbenbart også tankt på sin okonomi; i et brev til Nansen kalder T. ham ærgerligt en makulaturgrosshandlare.

Nansen tager fat på oversattelsen, og den 19. maj 1893 kvitterer Tavaststjerna fra Berlin for 168 Reichsmark; videre skriver han:

„I senaste nummar af Tilskueren ingår en af mina smärre noveller, tämligen godtyckligt öfversatt af fru Forsberg, och sedan omarbetad och redigerad af Galschiöt - Mycket bråk för en omelett! Och i alla fall lyser stycket af de mest kända fruntimmersstils banaliteter, sådana jag undviker af instinkt.

Kan Ni inte rekommendera mig en öfversättare, som åtminstone kan respektera mina tilstymmelser till stil, i stället för att alldeles utplåna dem? Men jag får godt honorar så snart jag låter mig banaliseras.".

Den omtalte novelle er "Impressionisten ". Alma Forsberg havde oversat novellesamlingen „Marin och genre", der med titlen „Genrebilleder fra Land og Sø" var udkommet på Gyldendal i 1892 . Irritationen, som forfatteren giver luft for, er berettiget nok, hvad oversættelsen $\mathrm{i}$ „Tilskueren" angår; flere stilistiske pointer er uden sproglig nødvendighed gået tabt.

Det synes knap så berettiget, når Tavaststjerna også vender sin irritation mod Galschiøt; det skulde da vare, fordi hans alineadeling ikke er blevet respekteret, men der er ingen større skade sket derved. Som redaktør af „Illustreret Tidende" havde Galschiøt optaget flere af Tavaststjernas mindre stykker, således allerede $19 / 8$ I888 en af hans bedste noveller „Ett misförstånd“. Flere af de senere optagne er oversat af Christian Gulmann, og da denne overtager redaktionen af „Gads danske Magasin" i 19o6, offentliggor han i et af de første numre sin oversattelse af "Impressionisten", der er adskilligt mere adækvat end fru Forsbergs. I efteråret 1893 tilbyder Galschiøt sig som oversætter af „I förbund med döden", og der er tale om, at den skal stå $\mathrm{i}$ fire numre af „Tilskueren“. Det bliver imidlertid ikke til noget, og Galschiøt får heller ikke, som han har stillet i udsigt, skaffet forlag til den, formentlig fordi Dagny Przybyszewska med sin norske oversættelse er kommet ham i forkobet.

Det var imidlertid ikke blot Galschiot, der tog Tavaststjernas mindre ting. Skitserne om landskaber og meteorologi, som han omtalte i det ovenfor citerede brev, stod i Nansens oversattelse i „Politiken“" under fallestitlen „Korte Breve fra en lang Bryllupsrejse“ $16 / 1,30 / 1,6 / 2,12 / 2$, 
20/2, 27/2,6/3, 13/3,20/3, 31/3 og 10/4 1893. De kom senere på svensk i bogform, og Tavaststjerna var ivrig for at få bogen ud i Danmark eller Norge - Cammermeyer synes at have varet interesseret - men det blev ikke til noget; de små rejsebreve er også for spinkle til at bære bogformen.

Inden „Hårda tider" var udkommet i Nansens oversættelse, fik Hegel en forskrakkelse ved at se Aschehoug i Kristiania annoncere en norsk oversattelse af samme roman. På Nansens forespørgsel fortalte den lige så konfunderede forfatter, hvorledes det hang sammen: „Hârda tider" var, kort efter at den var udkommet, blevet offentliggjort som feuilleton i „Verdens Gang“, men henimod slutningen var den blevet temmelig vilkårligt nedskåret, fordi bladet hurtigst muligt skulde begynde med en roman af Zola. Da Tavaststjerna overfor oversætteren, K. V. Hammer, havde klaget over denne fremgangsmåde, havde Hammer tilbudt ham som en art moralsk erstatning (der fandtes ingen litterare konventioner mellem Norge og Finland) at skaffe forlag til en uforkortet oversattelse af romanen. Tavaststjerna tog imod tilbudet, men havde ikke siden hørt noget derom, skønt han havde korresponderet med Hammer, der oversatte bryllupsrejsebrevene for „Verdens Gang“. Tavaststjerna fandt, at han med rette måtte have anset sagen for skrinlagt, og er nu meget ulykkelig ved tanken om at komme til at stå for Hegel i en falsk belysning. Han slutter sin lange redegørelse, dateret Ostsecbad Sellin, Rügen, 24/6 I 893 :

„Sänd mig därför vänligast upplysningar om huru jag bör handla! Jag kunde ju på eget godt samvete och bevåg tillskrifva firman, men hesiterar, då jag därmed kanske endast kunne förvärra en sak, som kan göras upp i godo.

Naturligvis berör det hela mig ytterst pinsamt. På det att Hegel ej må tro att det ligger någon spekulation under, så meddela honom, min kära Nansen, att den hotande norske konkurrensen ej inbringer mig ett öre. Det bör ju åtminstone vara ett faktum, hvilket alldeles fritvår mig i Edra och hans ögon - de enda inför hvilka jag är räkenskap skyldig. Och hälsa honom samt framför min ursäkt att jag ej är mera inkommen i literärt börsspel. Vore jag det, hade aldrig denna förargliga sak kommit och försökt rubba ett gryende gott förhållande mellan mig och nordens förnämsta förlagsbokhandel.

Själf skall Ni ha stort tack för ert resoluta sätt att tage mitt parti! Jag vill hoppas det hela kan aflöpa utan värre konflikter, befullmäktigande Eder att handla i mitt namn gent emot det norska förlaget på grund af de upplysningar jag i detta bref gifvit Eder om sammanhanget."

Hegel blev beroliget, kom overens med Aschehoug, og i oktober 1893 udkom så „Strange Tider". Tavaststjerna udtrykte sin tilfredshed: 
Käre Nansen!

Berlin W. Kurfürstenstr. 34, II.

d. I8. Okt. 1893 .

Härmeddels mitt uppriktiga tack för öfversättningen af Hårda tider, hvilken jag fått numera och med stort nöje genomläst.

$\mathrm{Ni}$ har, långt bättre än jag på min provinssvenska, lyckats få den soignerade språkliga prägeln på boken, hvilken den bör ha. Gyldendals distingverade utstyrsel gör sitt till för att den danska upplagan skall uppträda mera fulländadt än den svenska, och för alla dessa förmåner har jag ju ytterst att tacka Er!

Måtte bara boken fă en så pass bra afsättning att Hegel också härnäst vill taga något mitt arbete på sitt förlag! Den konkurrerande norska upplagan står långt efter den danska i yttre och inre hållning, men om den nu kunde göra sitt till för mina framtida möjligheter i Danmark och Norge, så vore ju dubbel upplagan alls inte att bli ledsen öfver.

Ifall några kritiker skulle sablat ner boken grundligt, hade den säkert haft bättre affärsvärde. Det nyktra estimerandet gör ingen fet, gunås, fast det kanske borde tagas som ett godt utslag under reklamlitteraturens æra.

Ännu engång, tack för godt bistånd! I hopp om yttermera samarbete,

Er förbundne

Karl A. Tavaststjerna.

Afsætningen kunde der ikke klages på. Oplaget var, som ved alle de tre bøger af Tavaststjerna, som Gyldendal udsendte, $1250+75$ exemplarer; af disse haftedes forst 850, strax derefter i5o, og endnu i r9or må bogen have været noget efterspurgt, da forlagskladden meddeler, at endnu 50 exemplarer er gået til hæftning.

Hvor oprigtig Tavaststjernas fremhavelse er af den danske udgave på de andres bekostning, skal lades uafgjort. J. Jorgensen i København og Malling i Kristiania kunde jo nok i teknisk henseende tage det op med Kuopio nya tryckeri, men den påståede forskel mellem den danske og den norske udgave er det idag vanskeligt at øjne; Hammers oversættelse står sig meget pænt ved siden af Nansens, tildels måske fordi det norske sprog virker naturligere i finske bønders mund end Nansens normalprosa.

Tavaststjerna havde imidlertid god grund til at holde Gyldendals interesse vågen; hans næste store roman, „Kvinnoregemente“, var omtrent færdig, og i januar 1894 sporger han Nansen, hvordan mulighederne er for dens udgivelse i dansk oversattelse.

Trods de tidligere lovende udtalelser fra Kobenhavn går det ikke så let med den nye roman som med „Hårda tider", hvilket $\mathrm{i}$ og for sig ikke 
kan undre. „Kvinnoregemente"s sigte er mere exklusivt finsk, og som kunstværk når den ikke „Hårda tider". Gyldendals tilsyneladende tøven har øjensynlig fået Tavaststjerna til at forsøge andre jagtmarker, men til sidst ender han dog hos Gyldendal og Nansen, lidt ængstelig for, hvad man vil mene om hans udbrudsforsøg. Har det varet hans tanke at få sig lidt bedre betalt, synes han at vare blevet skuffet. Trods alt er det ikkè uden lettelse, han den 17 . december 1894 takker for Nansens forståelse, han er tilfreds, når „Kvinnoregemente" kommer ud med Nansens navn på titelbladet.

"Ja, jag är Er tacksam, t.o.m.", skriver han, og indser så ved gennemlæsningen af brevet, at det kan klinge lidt ironisk, hvorfor han med et enkelt greb udelukker en sådan fortolkning, idet han retter til: "Ja, jag är Er tacksam, - t.o.m. mycket tacksam."

Imidlertid går månederne, og Tavaststjerna har på fornemmelsen, at der ikke er rigtig gang i oversættelsen, især efter at han har erfaret Nansens forlovelse med Betty Müller. Hans beskedne honorar fortoner sig $\mathrm{i}$ en uvis fremtid, og han skriver:

Käre Nansen!

Stockholm 2I Aug 95.

Jag hoppas Ni, sedan den glada underrättelsen om cr förlofning, hunnit realisera meningen med denna, d.v.s. gift Er. Af denna min supposition ser $\mathrm{Ni}$ att jeg ej flitigt läst "Politiken" $\mathrm{i}$ sommar, - i annat fall visste jag nog besked. Men jag gratulerar Er huru det än förhåller sig med saken, ty $\mathrm{Ni}$ är alltid en gratulabel person.

Dessa tider har jag med viss oro tänkt på möjligheten att Ni svikit Er store kärlek och börjat inspirera någon ny dotter af Eva Julies dagbok och Maries nycker. I så fall vill Kvinnoregementet låta vänta på sig, tyvärr.

Hoc est: jag inser att mina fattiga $200 \mathrm{kr}$. ligga i Er hustrus hand, så tillvida som hon er den hvilken disponerar öfver Ert intresse. Nu ska $\mathrm{Ni}$ inte tro att jag precis svälter ihjäl utan dem, men jag är i färd med att antaga redaktörsposten för en tidning i Hangö, Finland, och $\mathrm{Ni}$ vet bäst själf att en redaktör hälst bör gifva roo kronor i drickspängar åt kyparen, som serverar honom hans första kopp kaffe på den nya orten.

Af denna usla anledning träder min finkänslighet och vänskap och tacksamhet o.s.v. helt i bakgrunden och jag blir bara en sniken Yankec, såsom $\mathrm{Ni}$ redan sett att jag haft ämne till ur „Bröllopsresebrefven“. Allt detta beror på min lättja naturligtvis, ty i sommar har jag endast lefvat för sport och hälsovård. 
Om Ni nu detta oaktadt skulle ha lust att statuera exempel på den danska civilisationens öfverlägsenhet öfver den svensk-finsk-ryska, så tag Ni Hegel en dag i rockknappen och säg till honom: Beste hr St Olafsriddare, befria mig från den besten Tavaststjerna och sänd honom hans 200 kronor. Han tråkar mig till döds med sina omöjliga bref och då får Ni aldrig manuskriptet till hans roman, lika litet som min välsignelse till arbetets spridning!

Säg honom det, käre Nansen, och jag skall förlåta Er osanningen så gärna. Ty jag är viss på att Ni ljuger så behagligt och hyggligt att jag visst inte blir lidande på det. Och afdrag min gamla skuld till $\mathrm{Er}$, samt uppgif min adress: Dalarö, Sverige! Där fins jag till d 5 september.

Förlåt min ringa takt som jag förlåter lapparna deras!

\section{Med hälsningar, Er tillgifne}

Karl A. Tavaststjerna.

Brevet har ikke forfejlet sin virkning. Allerede den 30 . august takker Tavaststjerna for de tilsendte 200 kroner og besvarer samtidig I9 detailspørgsmål vedrørende oversattelsen. Den gamle gald på 4o kroner har Nansen tydeligvis eftergivet ham. Et par måneder senere udkom „Kvinderegimente".

Samme år som „Kvinderegimente " kom, I895, forsøgte Tavaststjerna at få endnu en roman ud på dansk: „Finska vikens hemlighet“, en spændingsroman uden storre pretentioner, som Tavaststjerna ventede sig en del af som salgsobjekt. Den handlede om den russiske monitor Rusalkas mystiske undergang i den finske bugt i 1893 og udkom under pseudonymet Paul Dubois. „Paul Dubois är en ganska djärf fransman. Nämn ej ett halft ord om att jag känner honom och är hans fullmäktige. Det kunde förskaffa mig deportation", skriver Tavaststjerna 22/2 I895, hvor han sporger, om Nansen kender nogen eventuel oversatter til den - selv er han jo optaget af „Kvinnoregemente“. Deraf bliver imidlertid intet.

Korrespondancen drejer sig, som venteligt er, mest om Tavaststjernas varker. Den 9. december 1894 slutter Tavaststjerna imidlertid et brev med disse linier:

„Till sist - sänd mig Er bok Maria, Mariana eller hur den heter! Jag vill gärna tycka om den som Lie, och skall nog göra det. När Ni ser Esmann så hälsa honom om $\mathrm{Ni}$ vågar göra det utan att fả duell på nacken. Sänd honom för öfrigt till Norge eller Schweiz för att sköta om sina nerver, det behöfver han."

Tavaststjerna făr „Maria“, der den 7. januar 1895 aflokker ham følgende: 
„Vi har njutit boken ofantligt här i Stockholm, vi som ha sinne för det ena och det andra. Där finnas satser, som borde stå i alla konfirmanders bibel, både gossars och flickors. Hanrejer och horor borde också läsa den för att lära sig kärlekens gudsțänst. Vackrare kan jag inte skrifva om den. Tack för nöjet ..."

Sådanne udtalelser må naturligvis leses cum grano salis. Forholdet mellem de to forfattere er jo starkt sammenvavet med begges egeninteresse; nogle småting hører imidlertid hjemme $\mathrm{i}$ billedet og giver det liv. Det er ikke blot romanerne, Nansen tager sig af; ovenfor er næunt de „Korte Breve fra en lang Bryllupsrejse“, og den 23. oktober I893 stod Tavaststjernas novelle „Pest" (humoristisk, om kolerafrygten) at lase i „Politiken“"i oversættelse ved O. L. (Otto Larssen?). Tavaststjerna boede på dette tidspunkt i Berlin og kvitterer for et honorar på Rm. 28.o5, hvorfor vi altså kan fastslå redaktionens taxering af forfatteren. I et brev fra Hørup til Bjørnson ( $18 / 1$ I 892 ) erfarer vi honorartaxterne: normalt 6 à 8 øre pr. linie, sjældne rangspersoner to øre. Honoraret for "Pest" beløber sig til $6^{1 / 4}$ ore pr. linie, hvad der må siges at vare ret pænt, da oversættelsen jo også skulde betales.

Den 9. december I894 skriver Tavaststjerna: „Som påpasslig journalist sänder jag „Politiken“ en kort résumé af Gustaf Adolfs festen i Stockholm. De äro galna af gammalt högmod här. Sätter Ni värde på det snabba meddelandet, så för in det genast, men låt ingen veta att jag gjort det! Jag kan för öfrigt meddela mer härifrån, om det intresserar."

Tavaststjernas "Stockholmsbrev" - „fra en flyvende Korrespondent", undertegnet Mahmud - kom strax i bladet den i i. december. Det er en af Tavaststjernas få helt vellykkede journalistiske ting; hans ondskabsfulde skildring af broderfolket i feststemning har sat et usædvanligt sving på artiklen, men det er let at forstă, at „Politiken “ ikke vilde risikere sit omdømme i Sverige ved at bringe flere artikler af samme skuffe, f. ex. „om Svenska Akademien och Posttidningens skandaler“, som Tavaststjerna stiller i udsigt.

Af et brev 14/6 I895 ser det ud som Nansen har lovet at antage nogle noveller til „Politiken", men løftet har muligvis ikke været konfirmeret på højere sted, så at bladet efter Nansens afgang - han tiltrådte på Gyldendal nytår 1896 - ikke har følt sig bundet. En art fortsættelse på bryllupsrejscbrevene „Korta bref frân hemmets lugna härd“ får Tavaststjerna ikke afsætning på (3o/9 1895); de hører også til hans svagere arbejder.

Ganske rørende virker et par journalistiske småtjenester, som Tavaststjerna beder Nansen gøre sig. Kritikken i Finland var sjældent objektiv; i de vanskelige år, landet nu gik ind til, var det $\mathrm{i}$ og for sig naturligt, at 
de fleste kulturytringer i nogen grad underordnedes de store nationale og politiske spørgsmål. At dette ikke kunde være tilfredsstillende for „friseglaren“ Tavaststjerna behøver ingen nærmere forklaring. Så meget mere betød selv den mindste linie i et udenlandsk blad, og 30/r 94 beder Tavaststjerna Nansen om at sætte lidt i „Politiken“" om ham og hans produktion, da det vil få større vægt, hvis det citeres i hjemlandets presse efter det danske blad; og så stod med mindste skrift under „Smæld og Smuld" den 24. februar disse linier:

„Karl A. Tavaststjerna har nylig af det svensk-finske Litteraturselskab modtaget en høj Prisbelønning for sin sidste Bog I Forbund med Døden. Paa Tysk udkommer denne Novelle hos E. Pierson i Dresden. Ogsaa den nye Roman, som Tavaststjerna arbejder paa, er allerede paa Forhaand erhvervet af et stort tysk Forlag."

Det synes beskedent; men det var nok til at forfatteren med stor tilfredshed så det citeret i "Nya Pressen".

$\mathrm{Da}$ Tavaststjerna i efteråret $\mathrm{I} 895$ overtog redaktorstillingen ved det ret ubetydelige provinsblad „Hangö", bad han atter Nansen om en notits i "Politiken" om Tavaststjernas påtænkte modernisering af „Hangö". Der synes ikke at vare blevet noget af hverken notitsen eller moderniseringen - Tavaststjerna blev kun i Hangö i tre måneder. Men det viser tydeligt „Politiken "s anseelse i radikale kredse overalt i Skandinavien: skulde man vise, hvilken karl man var, behøvede man blot at nævnes i „Politiken“.

Det sidste brev i samlingen er dateret Hangö 20/1 2 1895 og indeholder disse linier:

"Jag behöfver stöd från utlandet. Allra mest angående denna bok („Kvinnoregemente“), som härhemma totalt missuppfattats i likhet med allt hvad jag numera skrifver. Det blir alltid politiskt och slås i hjäl af dygnkritiken."

Det er symptomatisk, at det slutter med meddelelsen om Tavaststjernas forestående flytning til Björneborg, hvor han skal overtage redaktionen af „Björneborgs Tidning“. Tavaststjernas liv i denne by har han selv kaldt en "frivillig begravning"; en depression, hvis komponenter det ikke her er stedet at udrede, havde hårdt tag i ham, og den tiltagende døvhed gjorde sit til at isolere ham. Det er i Tavaststjernas tilfælde ikke en frase, at døden kom som en befrier, da han bukkede under for en lungebetændelse den 20. marts 1898 , knap $3^{8}$ år gammel.

Georg Brandes gav ham et smukt eftermæle:

„Tavaststjerna var visselig en af det unge Finlands fineste og mest omfattende Aander. Ingen havde givet saa store Lofter som han, ingen 
stod saa højt i lyrisk Evne og i Lune, ingen var paa en Gang saa kraftigt finsk og saa moderne europaisk. Store Evner havde han, Mesterskabets Klang og Pragt i sine Vers, og dog var han dæmpet, stilfærdig, stilfuld og velopdragen som en xgte Finne. Hvor var det vemodigt at se ham i de sidste Aar, da Sygdom havde hærget ham og næsten lukket hans Øre for Livets Lyd!"

Men som direktør på Gyldendal sorgede også Peter Nansen for Tavaststjernas eftermæle; i 1907 udkom "Strænge Tider" i Gyldendals vidt udbredte „Bibliothek for Hjemmet", og derved fandt dette hovedvark sin plads på mangfoldige danske boghylder. 